\title{
Shared interests foster interethnic cooperation among politicians
}

\author{
Daniel Butler ${ }^{1 *}$ (D) and Margit Tavits ${ }^{2}$ \\ ${ }^{1}$ Political Science, University of California San Diego, La Jolla, California, USA and ${ }^{2}$ Political Science, Washington University \\ in St. Louis, St. Louis, Missouri, USA \\ *Corresponding author. Email: daniel.butler@gmail.com
}

(Received 17 December 2018; revised 15 October 2019; accepted 27 October 2019; first published online 23 April 2020)

\begin{abstract}
Ethnic relations play an important political role in many countries and can have serious consequences for policy and stability, with many conflicts occurring along ethnic lines. While most studies on ethnic relations focus on the behavior of the general public, ethnic bias among political elites may be equally consequential but remains understudied. This study explores tools that improve interethnic cooperation among politicians in governance (rather than electoral competition). We argue that shared interests incentivize elites to overcome ethnic bias. We conduct two experiments (one survey and one lab-in-the-field) with local politicians in Bosnia and Herzegovina and find support for this expectation, i.e., concrete information about shared policy priorities and goals foster interethnic cooperation.
\end{abstract}

Key words: Ethnicity and nationalism; experimental research

Ethnicity plays an important political role: individuals often vote along ethnic lines (e.g., Posner 2005; Ferree 2006; Huber 2012; Ichino and Nathan 2013; Adida 2015; Carlson 2015) and are more altruistic and trusting toward coethnics (Whitt and Wilson 2007; Robinson 2016b). Ethnic favoritism affects whether and when voters hold governments accountable for bad performance (Adida et al. 2017), and shapes economic transactions (Michelitch 2015; Robinson 2016a), government responsiveness (McClendon 2016), and public resource allocation (Franck and Rainer 2012; Kramon and Posner 2016). ${ }^{1}$ Such favoritism can negatively affect important political outcomes, such as development and democratic stability (Chandra 2005; Posner 2005). In some cases, it can also lead to violent conflict (Horowitz 1985; Gurr 2000).

Prior research shows that political elites play an important role in fostering ethnic favoritism by taking purposeful actions (such as ethnic based appeals) that politically activate ethnic divisions (Bates 1983; Chandra 2004; Tavits and Potter 2015). ${ }^{2}$ In contrast, we look at the role of elite behavior in the context of governing, where elite's own ethnic bias (rather than their ethnic-

\footnotetext{
${ }^{1}$ But see Burgess et al. (2015), who show that ethnic favoritism in public goods provision is less likely under democracy than non-democracy.

${ }^{2}$ It is possible that elites sometimes strategically misrepresent the motivations of the ethnic other to strengthen their own base of support, not because of their distrust in those elites (de Figueiredo and Weingast 1999). However, many studies continue to argue that to avoid ethnic tensions in divided societies, we should incentivize cooperation among elites (Rothchild 1997; Lijphart 2012). Referring to Bosnia, Keil and Kudlenko (2015) argue that ethnic tensions have not been fully resolved because of the lack of trust and willingness to cooperate among elites.

(C) The European Political Science Association 2020. This is an Open Access article, distributed under the terms of the Creative Commons Attribution-NonCommercial-ShareAlike licence (http://creativecommons.org/licenses/by-nc-sa/4.0/), which permits non-commercial re-use, distribution, and reproduction in any medium, provided the same Creative Commons licence is included and the original work is properly cited. The written permission of Cambridge University Press must be obtained for commercial re-use.
} 
based appeals) may play an important role. Looking directly at politicians' own ethnic biases is important because, to reduce ethnic tensions, we need to understand when and why political elites are motivated to pursue interethnic cooperation. Furthermore, prior work informs us that politicians' behavior cannot simply be deduced from studies of mass behavior (LeVeck et al. 2014; Butler and Kousser 2015).

What fosters interethnic cooperation among elites in deeply divided societies? Prior research on ethnic conflict and cooperation has shown that existing circumstances play a large role in whether ethnic identity becomes politically salient (Laitin 1986; Chandra 2005; Posner 2005). A prominent explanation associates the moderation of ethnic divisions to the presence of identity-based cross-cutting cleavages (e.g., class, religion, and cousinage) along which members of the same ethnic group have different allegiances that they share with members of other ethnic groups (e.g., Lipset 1960; Dunning and Harrison 2010; Gubler and Selway 2012). The competing allegiances are likely to dampen ethnic favoritism.

Rather than studying identity-based cross-cutting cleavages, we focus on the extent to which shared interests can help overcome ethnic bias among political elites. Shared interests refer to policy preferences or goals that the members of different ethnic groups have in common. Reminding political elites of their shared interests with non-coethnics can undercut in-group bias and increase interethnic cooperation. When information about shared interests and common goals is absent or ignored, politicians rely on ethnic cues for determining which other politicians are likely to share their preferences (cf. Ferree 2006). Providing and highlighting such information may effectively moderate the political salience of ethnic identity in elite behavior.

We test our argument with experiments (one survey and one lab-in-the-field) among political elites in Bosnia and Herzegovina (BiH hereafter) - a site of an ethnic war between all three of its major ethnic groups. If shared interests facilitate cooperation in a society following ethnic conflict, such interests are likely to be even more effective in fostering cooperation in less deeply divided societies. $\mathrm{BiH}$ is a good case for our purposes for two other reasons. First, there are no major, cross-cutting identity cleavages in $\mathrm{BiH}$. The other major division-religion-falls along ethnic lines: the Bosniaks are Muslim, the Serbs are Orthodox, and the Croats are Catholic. If the major ethnic groups in $\mathrm{BiH}$ are to achieve interethnic cooperation, it must be through some means other than an existing, crosscutting identity. Finally, the role of elites is especially important in $\mathrm{BiH}$ because the political system has, by design, delegated interethnic cooperation to elites.

Our experiments were conducted as part of a survey of local political elites in $\mathrm{BiH}(N=1389)$. We designed these experiments to study whether common interests increase the willingness of individuals to work with non-coethnics. In line with expectations, Experiment 1 shows that officials' bias in favor of a coethnic collaborator is significantly reduced when they learn that a potential non-coethnic collaborator shares their policy priorities. In Experiment 2, we find that priming officials to think about the benefits of the EU-a common pan-ethnic goal-leads some officials, though not all, to exhibit higher levels of cooperation with non-coethnic politicians in a trust game. Our results advance theories of interethnic cooperation and provide encouraging signs for policy-makers tasked with improving ethnic relations in divided societies.

\section{Shared interests and cooperation: theoretical argument}

Recent research on ethnic relations argues that ethnicity often acts as an information shortcut about shared interests among members of the same group (Chandra 2004; Posner 2005; Ferree 2006). This suggests that ethnic voting could arise from voters using ethnicity as a cognitive shortcut about who is most likely to share and pursue their preferences (Ferree 2006; see also Abrajano and Alvarez 2005; Posner 2005; Carlson 2015). The work on cross-cutting cleavages echoes this perspective: such cleavages are argued to dampen ethnic conflict because they create interdependencies between otherwise potentially antagonistic groups by highlighting shared 
interests across ethnic lines (Coser 1956). This argument about ethnicity (or other group membership) as informational cue has primarily been applied to analyzing the electoral choices of voters. ${ }^{3}$ We extend this argument to political elites and apply it to cooperation in governance.

We argue that access to information about shared interests across different social groups leads to gains in inter-group cooperation among political elites. ${ }^{4}$ Such shared interests can take the form of shared policy preferences or priorities, or common goals. Information on shared interests can reduce inter-ethnic bias among elites for the following reasons. First, as summarized above, the primary role of a social cleavage is to serve as a signal of shared values and interests with the other members of that cleavage (e.g., Chandra 2004; Hale 2004; Posner 2005; Ferree 2006; Lieberman and McClendon 2013). Yet signals are imperfect-not all members of the same social group think alike. Obtaining concrete information about shared interests with out-group members decreases the need to rely on identity as an imperfect signal of such interests. Unless interests are always perfectly collinear with ethnic identity, such concrete information should therefore increase the likelihood of inter-ethnic cooperation among politicians. ${ }^{5}$

Second, information on shared interests redirects individuals' attention away from the social category that divides them (ethnicity) to a different category that unites them (shared interests) (Gaertner et al. 2000; see also Sherif 1966). That is, such information incentivizes individuals to conceive of (at least some) non-coethnics as part of a new in-group (e.g., the group that shares their preferences). Ethnic bias is therefore reduced through the process of recategorization of noncoethnics from out-group to in-group (Hewstone et al. 2002).

For the sake of illustration, imagine two politicians from different ethnic groups. In the absence of information about shared interests, neither politician has incentives to look beyond ethnic differences and seek cooperation in governance. Each politician, interested in pursuing a policy priority or a goal, is better off seeking allies within his or her own group because the shared identity provides a reasonable expectation of potential for shared values and interests. In such a case, in-group favoritism and out-group antagonism are likely to dominate, i.e., politicians are more likely to cooperate with in-group than out-group members. In fact, antagonism may run deep if the groups believe that they have explicitly different and conflicting policy priorities or goals.

Information about shared interests with members of the out-group, on the other hand, paves the way for establishing common ground between politicians from different ethnic groups. Such interests provide a reason for communicating and cooperating with the out-group politicians. ${ }^{6}$ When information about shared interests is available and made salient, politicians no longer need to rely on an imperfect, identity-based signal about the potential of commonalities. Rather, information about shared interests shifts politicians' attention away from identity-based differences, which loosens the barriers to cooperation that heightened ethnic-based social identity induces and sustains. In sum, we expect that shared interests increase the level of cooperation between politicians from different ethnic groups.

\footnotetext{
${ }^{3}$ But see Adida et al. (2017) for a criticism; this study argues that due to ethnically motivated reasoning, performance information will actually enhance and not diminish ethnic voting.

${ }^{4}$ Habyarimana et al. (2007), studying a group of citizens in Uganda, find that preferences do not correlate with ethnicity and conclude that the level of ethnic bias cannot be driven by shared preferences. In contrast, we focus on how to change the level of bias and whether information that one shares preferences with a non-coethnic can produce such change.

${ }^{5}$ This argument is in line with some studies in political psychology, which argue that in-group favoritism is the result of interdependence (implied or actual) between in-group members. Consequently, introducing interdependence with out-group members can promote out-group favoritism (Rabbie et al. 1989; Yamagishi et al. 1999). Such interdependence refers to common fate or expectations of reciprocity (see Balliet et al. 2014 for a review), and we see it as conceptually similar to our notion of shared interests or goals.

${ }^{6}$ Sharing interests does not presume that both parties prefer a universalistic policy. Individuals from two different groups can support project A over project B because it advances the interests of their own group. Furthermore, a short-term ability to cooperate across ethnic lines because of a fortuitous alignment of interests may have no spillover effects on future cooperation (see Hale 2004), but common preferences can.
} 


\section{Case selection}

We test whether shared interests help foster interethnic cooperation by fielding experiments with local politicians in ethnically divided $\mathrm{BiH}$. Ethnicity became a particularly salient identity in $\mathrm{BiH}$ during the conflict in 1990s, which was carried out along ethnic lines. Since that conflict, the different ethnic groups have created strong enclaves that reinforce ethnic divisions (Busby 2018) and lack of other cross-cutting cleavages helps sustain them. Post-war institutions also played an important role in freezing the ethnic divisions in place: the 1995 Dayton Peace Agreement, which ended the fighting, established a consociational government with the ethnic Bosniaks, Serbs, and Croats being equally represented. For example, voters in $\mathrm{BiH}$ elect three presidents: a Serb, a Bosniak, and a Croat. The chair of the presidency then rotates among the three members every eight months over their four-year terms. Similarly, the upper house of the legislative branch is composed of an equal number of each of the three ethnic groups. Voters from each ethnic group elect the representatives for their own group. The political system is explicitly designed along ethnic lines, reinforcing the salience of ethnicity for both voters and politicians. As a result, mostthough not all-political parties in Bosnia are based on ethnic identity and nationalism (Stojarová 2010; Keil and Perry 2015). Furthermore, while most acute at the national level, ethnic divisions are also salient in local government (Jokay 2001; Kapidzic 2016).

While most political parties in Bosnia are focused on the narrow interests of one ethnic group, a few multiethnic parties compete in and win elections. These parties include the Our Country (NS), the Democratic Front (DF), and the Social Democratic Party (SDP) (Šedo 2010; Keil and Perry 2015). In the 2018 elections, they won 10 of the 42 seats in the House of Representatives and 2 of the 15 seats in the House of Peoples. These multiethnic parties are an exception to the rule, but they show that inter-ethnic cooperation can occur in Bosnia. We test whether shared interests boosts such cooperation among politicians in the context of governance.

\section{Empirical strategy}

We study politicians because they are key opinion leaders in interethnic cooperation. Politicians are the ones who politicize (or downplay) ethnic identity among the general population (Bates 1983; Chandra 2004). If we wish to increase general levels of interethnic cooperation, the most direct way of doing so is by increasing cooperation among elites. The behavior of elites is particularly important in $\mathrm{BiH}$ due to its consociational political institutions where negotiations, at least at the federal level, are delegated to elected officials from the different ethnic groups.

We opted for an experimental design to directly manipulate shared interests. This design thus allows us to hold constant a host of potential confounders, such as party affiliation (ethnic or multi-ethnic) and the ethnic composition of the municipality that might affect elite level cooperation.

We conducted an original survey of municipal level politicians in $\mathrm{BiH}$ from November 2015 through March 2016. The survey firm IPSOS conducted face-to-face interviews with 1389 local politicians (members of municipal councils $(N=809)$ ) and politicians who had run for such office in the most recent municipal election $(N=580)$. This constitutes a relatively unique and hard to reach sample in the comparative context. Interviews were conducted in all municipalities except two where the local councils opted out. Additional information about the survey is provided in Online Appendix (OA) section 1.

Our sample is reflective of the ethnic diversity of $\mathrm{BiH}$. Bosniaks comprise 45 percent of our respondents, Serbs 35 percent, and Croats 17 percent. This ethnic breakdown is similar to that in the general population. Women represent 27 percent of the sample and elected officials constitute 58 percent of the sample. The majority of interviews (61 percent) were conducted in the Federation of Bosnia and Herzegovina, the larger of the two entities in federal $\mathrm{BiH}$.

In the survey, we conducted two experiments: Experiment 1 is a vignette experiment and Experiment 2 a lab-in-the-field experiment. Both studies were designed to measure the 
willingness of local politicians to cooperate with a non-coethnic partner, and to estimate the extent to which exposure to information about shared interests alters this willingness. The vignette experiment uses a real policy scenario, which increases the possibility of external validity of Experiment 1. At the same time, the lab-in-the-field experiment uses more subtle priming of shared goals, and measures elite behavior rather than opinions, both of which amount to a more conservative test of the argument. The experiments are also complementary in that they focus on slightly different facets of interethnic cooperation: collaboration (Experiment 1), which is a more specific outcome, and trust (Experiment 2), which is a more general outcome.

\section{Experiment 1. The effect of shared policy priorities on interethnic cooperation}

Our first experiment focuses on the effect of shared policy priorities (an indicator of shared interests) on interethnic cooperation. We set up the experiment by asking respondents, in the section on demographic items, the following question:

Here is a list of some issues that local governments deal with. Please rank the issues in the order of importance to you in your municipality. 1= Most important and 4 =Least important.

Officials were shown the following issues: childcare, education, maintaining roads, and political participation. ${ }^{7}$ This allowed us to identify each respondent's most and least important policy issue-information we use for the "shared interests" condition. ${ }^{8}$

Later in the survey, we presented a vignette that asked respondents about partnering with an official to seek funds from the European Union via the Instrument for Pre-accession Assistance (IPA). The IPA program designates money for development and institution building in countries, such as Bosnia, that may join the EU in the future. Local and regional governments and various non-governmental organizations can apply for these funds, and collaboration is often encouraged. ${ }^{9}$ This allowed us to present the respondents with a very realistic scenario. Further, the IPA program is not unique. Other organizations, such as the OSCE Mission to Bosnia and Herzegovina, the Council of Europe, and local Association of Towns and Municipalities run various schemes where cross-municipal cooperation is necessary to receive a benefit or an award (World Bank 2009). Although officials recognize the benefits and incentives (electoral and otherwise) to cooperate with peers from other municipalities (World Bank 2009), they still often fail to do so (Jokay 2001, 99; Avramovic 2017). At least part of this failure is due to the "environment of pervasive mistrust among groups" (Avramovic 2017; see also Keil and Kudlenko 2015). Our study is designed to directly address these real-world cooperative dilemmas by building trust.

In the vignette, we presented respondents with information about two other officials and then asked them which one of the two they would choose to work with to apply for IPA funds. The text of the control version of the vignette, presented to a random half of the respondents, is shown in Figure 1.

We randomized the ethnicity of Official 1 and Official 2 to measure the level of favoritism toward coethnics. In each case, one of the two officials was randomly assigned to be the respondent's coethnic. The other official was a non-coethnic (we randomly chose which group the

\footnotetext{
${ }^{7}$ We picked these issues because local government is responsible for them and they are covered by IPA funding described in the subsequent survey experiment.

${ }^{8}$ Politicians from all three groups prioritize child care and education more than roads and political participation. Yet, there are still some differences between the groups, e.g., 73 percent of Serb politicians prioritized child care compared to only 54 percent of Croats and Bosniaks. Similarly, only 18 percent of Serb politicians listed education as the top priority compared to 36 percent of Croats and Bosniaks.

${ }^{9}$ See the European Commission (https://ec.europa.eu/neighbourhood-enlargement/instruments/overview_en) for more information.
} 


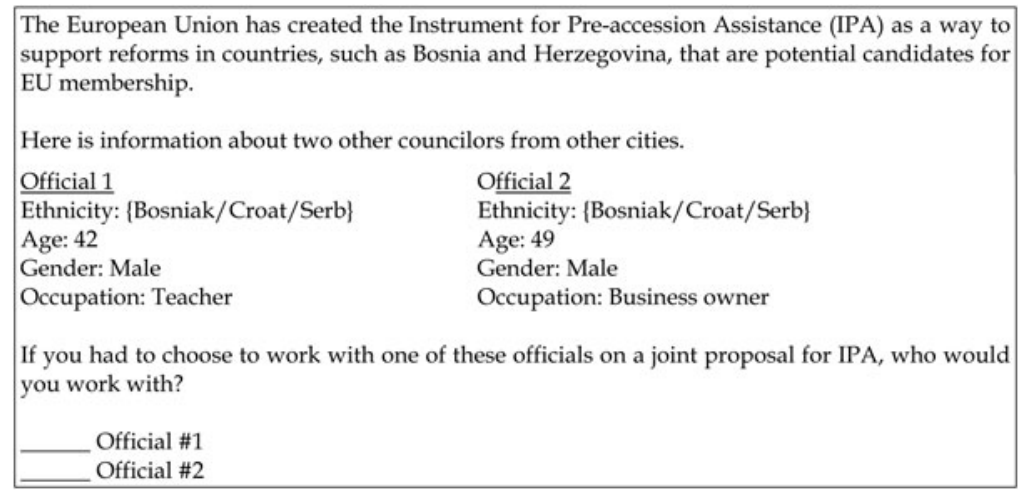

Figure 1. Text of control condition for vignette on seeking IPA funds.

non-coethnic official was from). In addition to the information on ethnicity, the bios included information about the potential collaborators' age, gender, and occupation. These additional pieces of information were not varied; they are included because a politician might use this information in making decisions about who to work with.

In the treatment condition, we also provided information on the policy priorities of Officials 1 and 2 by adding a line at the bottom of the bios. We designed the experiment such that the coethnic always wanted to work on an issue that was a low priority for the respondent, and the noncoethnic wanted to work on an issue that was a high priority for the respondent. ${ }^{10}$

In the experiment, we ask politicians about collaborating with councilors from other municipalities because that is the main way in which cross-ethnic collaboration can occur. To illustrate this point, Figure 2 displays the ethnic composition of the 142 municipalities in Bosnia covered by the 2013 national census with each point showing how much of the population corresponds to each of the three ethnic groups. The points near the corners of the plot are municipalities dominated by one ethnic group. As the data show, most municipalities are ethnically homogenous. In fact, in 102 of the 142 municipalities (i.e., 72 percent), the largest ethnic group represents 80 percent or more of the population. This intra-municipal ethnic homogeneity means that the opportunity to collaborate occurs across municipalities-a feature we capture in vignette.

The IPA program that we study (and cross-municipal cooperation in general) is not a zerosum negotiation. The politicians are encouraged to collaborate and the benefits for one politician do not come at a cost to the other. Several real-world collaborations in Bosnia are of this kind. Further, the issues that are included in the study-e.g., roads and education-are essentially valence issues about which the different ethnic groups can share a common preference: if both prioritize roads, both likely want better roads; if both prioritize education, both want better education. This contrasts with zero-sum or positional issues, i.e., divisive issues where different groups have opposing directional preferences, such as gun control or immigration in the USA. In that case, a benefit or policy victory for one side will come at a cost to the other side. It will be harder to find a solution in settings where groups have opposing positional goals. More generally, studying a cooperation opportunity that is not zero-sum (like we do) means that it may be easier to find an effect than under circumstances where bargaining is zero-sum.

\footnotetext{
${ }^{10}$ As an example, if a respondent who assigned to the treatment condition had listed education as their top priority and maintaining roads as their lowest priority, then in the vignette their coethnic would want to work on an IPA proposal focused on maintaining roads (the respondent's lowest priority) and the non-coethnic would want to apply for funds to improve education (the respondent's highest priority).
} 


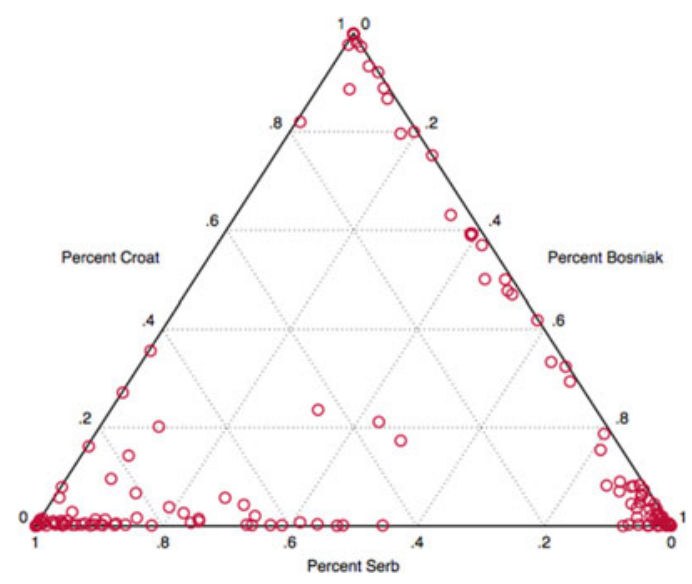

Figure 2. Ethnic composition of the population of municipalities in Bosnia.

Notes: The dots represent the ethnic composition of each municipality.

Data source: The 2013 national census.

\subsection{Experiment 1: results}

A comparison of the control and treatment conditions shows how much shared priorities can overcome the existing ethnic bias. Recall that the control condition itself provides the baseline for ethnicity's importance. If ethnicity is all that matters, then we would expect the officials to always choose to work with the coethnic in the control condition. If, however, ethnicity did not matter at all, we would expect the officials to choose to work with the coethnic 50 percent of the time in the control condition (because ethnicity was randomized in the bios). We can then see how much providing information on policy priorities changes these preferences. If ethnicity always trumped policy priorities, then we would expect information to have no effect on the propensity to choose the coethnic partner. In other words, providing the information about the shared priorities would have no effect on the likelihood of choosing a coethnic. However, if shared priorities do matter, we would expect officials to be much less likely to choose the coethnic partner (because that partner does not share their policy priorities).

Table 1 provides a summary of the results. It presents the share of individuals in both experimental conditions that chose to work with the coethnic, and the difference in these shares (along with the associated standard errors). The first column gives the results for the full sample, while columns 2-4 give the results by the respondents' ethnicity. The subgroup analyses in columns 24 were not part of our original plan and should be viewed as exploratory.

The results reveal that providing information on policy priorities decreases the likelihood of choosing one's coethnic. If officials were choosing a partner without respect to one's ethnicity, we would expect them to choose a coethnic 50 percent of the time. However, column 1 shows that in the control condition (i.e., absent information on policy priorities), officials chose the coethnic about two-thirds of the time. This is statistically different from 50 percent, the no bias benchmark $(\mathrm{p}<0.0001)$.

When learning that the coethnic did not share their policy priority but the non-coethnic did, officials only choose the coethnic one-third of the time. The 33-percentage point difference shows that officials were extremely responsive to considerations regarding the policy priorities of their potential working partners. ${ }^{11}$ In other words, information about shared priorities substantially increased the likelihood of interethnic cooperation. Of course, sharing policy priorities does

\footnotetext{
${ }^{11}$ We do not believe that social desirability bias affects this result. First, several recent studies show that demand effects are not a major concern in survey experiments (White et al. 2018; Mummolo and Peterson 2019). Second, randomization ensures that any desire to not show ethnic bias will be equal across the treatment and control conditions. Finally, even if such pressure exists, it is likely to work against finding a significant treatment effect because all respondents would feel obliged to not show bias.
} 
Table 1. The effect of shared policy priorities on choosing to work with a coethnic

\begin{tabular}{|c|c|c|c|c|}
\hline $\begin{array}{l}\text { DV }=\% \text { Choosing coethnic } \\
\text { Sample: }\end{array}$ & $\begin{array}{l}(1) \\
\text { All }\end{array}$ & $\begin{array}{c}\text { (2) } \\
\text { Bosniaks }\end{array}$ & $\begin{array}{c}(3) \\
\text { Croats }\end{array}$ & $\begin{array}{l}(4) \\
\text { Serbs }\end{array}$ \\
\hline Control & $65 \%$ & $56 \%$ & $73 \%$ & $73 \%$ \\
\hline Policy preference treatment & $32 \%$ & $37 \%$ & $41 \%$ & $20 \%$ \\
\hline Difference & $\begin{array}{r}-33^{*} \\
(3)\end{array}$ & $\begin{array}{r}-20^{\star} \\
(4)\end{array}$ & $\begin{array}{r}-31^{\star} \\
(6)\end{array}$ & $\begin{array}{r}-52^{*} \\
(4)\end{array}$ \\
\hline Observations & 1342 & 620 & 232 & 490 \\
\hline$R^{2}$ & 0.11 & 0.04 & 0.10 & 0.26 \\
\hline Difference in treatment effect & $\begin{array}{l}\text { ic grou } \\
\text { Serbs } \\
\text { Serbs }\end{array}$ & & $\begin{array}{r}-32^{*} \\
(6) \\
-20^{\star} \\
(7)\end{array}$ & \\
\hline
\end{tabular}

Notes: ${ }^{\star} \mathrm{p} \leq 0.05$ (two-sided). Standard errors in parentheses.

not completely eliminate the preference to work with a coethnic; if it had, then no one in the treatment condition would have chosen to work with their coethnic. ${ }^{12}$

Columns 2-4 show the results by ethnic group, which should be viewed as purely exploratory. Several interesting points emerge. First, the rate of choosing coethnics is statistically different from the 50 percent threshold in all cases. This means that even in the control condition all of the officials exhibit a bias for working with a coethnic. Second, shared policy priorities decrease the baseline preference to work with coethnics and increase the likelihood of interethnic cooperation for all three ethnic groups: for Bosniaks, Croats, and Serbs. Third, there are some differences across ethnicities in the magnitude of the effect. In the control condition, the Croat and Serb respondents showed a stronger preference for working with a coethnic than the Bosniak respondents (73 percent versus 56 percent) indicating a higher level of baseline in-group preference. Of the three ethnic groups, the Serbs were the most likely to change their choice to a non-coethnic working partner in response to information about policy priorities. The Serb respondents' likelihood of working with a non-coethnic increased by 50 percentage points in response to information about shared priorities. This is the largest change and it is also statistically significant relative to the shifts for Bosniaks and Croats (see the bottom of Table 1).

In sum, our first experiment provides evidence that shared interests help foster cooperation across ethnic lines. Shared interests increase the likelihood of interethnic cooperation by one third, on average, and by one-half for the Serbs. Recall that we find such a sizable effect in a deeply divided society that is emerging from the ruins of a devastating ethnic civil war. This finding bodes well for efforts to increase interethnic (and potentially other inter-group) cooperation in divided societies. It suggests that interethnic cooperation does not solely depend on difficult-to-change contextual factors, but can be achieved by shifting individuals' attention from identities to interests. What is more, our experiment offers a very concrete policy tool that national or international actors can use to induce cooperation: project-based funding that requires partnering with other municipalities or groups.

The results so far are encouraging. But how far can we push the idea that shared goals can foster cooperation? Do local politicians also respond to less concrete information about shared goals, such as shared national level (i.e., pan-ethnic) ideals and aspirations? Are more diffuse forms of mutual acceptance-such as cooperation with out-group members-also affected?

\footnotetext{
${ }^{12}$ These results are not driven by the specific issue priorities of the respondent. Specifically, one concern is that political participation is the least important issue for most respondents, suggesting that there might be something unusual about that issue. However, when we only focus on the subsample of respondents who chose something other than political participation as the least important issue, we find the same pattern with 59 percent of the control and 33 percent of the treatment choosing a coethnic partner.
} 
Can we observe changes in actual rather than just intended behavior? We designed Experiment 2 to explore these questions.

\section{Experiment 2. The effect of shared pan-ethnic goals on interethnic cooperation}

Experiment 2 was conducted as a separate part of the survey and set up as a lab-in-the-field experiment. While Experiment 1 focused on the effect of shared policy priorities, in this study, we test whether priming politicians to think about a common pan-ethnic goal leads to higher levels of interethnic cooperation among them (as measured by their behavior in a trust game). In Bosnia, the possibility of EU membership is one such highly desirable pan-ethnic goal. In our study, we prime politicians to think about the benefits of EU membership. ${ }^{13}$ This treatment is potentially invoking many different things. In the open-ended responses, the politicians noted several benefits including the ability to travel more easily and economic gains (see OA2.1). We are not identifying what about EU membership is attractive. The goal of this experiment is to prime country-wide priorities (as opposed to ethnic ones) more broadly, and EU accession is a good way to do so. Finally, note that compared to Experiment 1, this is a more indirect and subtle way of reminding respondents of shared priorities/interests, which sets an uphill battle for the empirical test.

We used the trust game to get a behavioral measure of levels of cooperation. It helps overcome the concern that the vignette design in Experiment 1 is simply cheap talk and that ethnic biases cannot be overcome when there are costly stakes involved (e.g., Habyarimana et al., 2007; Whitt and Wilson 2007). For this study, participants played four rounds of the trust game, which we modeled on the work done by LeVeck et al. (2014) and Iyengar and Westwood (2015).

The key part of the experiment is that we primed a randomly-chosen half of the officials to think about the benefits of EU membership (treatment group) before playing the trust game, while the other half played the trust game without receiving the prime. ${ }^{14}$ The officials in the treatment group were asked the following open-ended question: "Bosnia and Herzegovina is one of the countries that is under consideration for future EU membership. Please tell us what you think the benefits of EU membership are." The enumerators then recorded keywords for their responses. Note that for our purposes, it is not the content of these responses ${ }^{15}$ but the fact that officials had to think about the benefits of the EU membership that constitutes the treatment.

\subsection{Setup of the trust game}

A trust game takes place between two individuals (Player 1 or "trustor" and Player 2 or "trustee"). It was originally developed for lab experiments but is increasingly used in the field as a behavioral measure of how much trust Player 1 puts in Player 2 (see Robinson 2016b). In research on postconflict societies (Horowitz 1985; Gibson 2004; Whitt 2010), the terms trust and cooperation are often used interchangeably. In other instances, one is used to help define the other, e.g., "generalized trust refers to the degree to which people are willing to cooperate" (Bouckaert and Dhaene 2004,870 ). We follow this conceptualization of trust and cooperation in our study.

The game is played as follows. Player 1 is given an endowment, and a choice of how much to keep and how much to share with Player 2. That amount is multiplied (in our case tripled) and

\footnotetext{
${ }^{13}$ Our setup assumes that thinking of the benefits of joining the EU reminds local politicians of the shared aspirations that they have with the other ethnic groups in Bosnia, and allows us to test whether shared goals foster interethnic cooperation. We find support for this assumption from officials' qualitative responses to the treatment question as described in footnote 15 and OA2.

${ }^{14}$ The experimental groups were re-randomized with respect to Experiment 1.

${ }^{15} \mathrm{OA} 2$ provides descriptive information about the types of benefits that the respondents listed. In line with our argument that accession to the EU represents a common pan-ethnic goal, the items on the list are all common goods that would benefit all ethnic groups and not just some. That is, respondents do not see the EU as a tool to advance the interests of their ethnic group at the expense of the other groups. About 13 percent of the treated respondents stated that there are "no benefits" to EU membership.
} 
given to Player 2. Player 2 then has a chance to decide how much money to give back to Player 1 . If Player 1 trusts that Player 2 will return at least as much as he or she gives, then Player 1 should be willing to give more money. In this way, we get a tangible measure of how much Player 1 trusts Player 2.

For our study, all the respondents played the game as Player 1, i.e., the player who receives the initial endowment and then must decide how much to give to Player $2 .{ }^{16}$ Following the protocol used by LeVeck et al. (2014), the initial endowment was 10 tokens (we also explained that each token represented 100 Bosnian marks, or roughly \$50). Before playing the game, the respondents all received instructions on how the game was played followed by three hypothetical examples to reinforce the information in the instructions. The text for the instructions and examples closely followed the work of LeVeck et al. (2014) and can be found in OA3.

The last page of instructions explained that officials would be playing to benefit the local schools in their municipality. We paid out one reward so that we could offer a sizeable enough amount to get politicians invested in the outcome. Further, playing for a local school avoided any ethical and legal concerns that might occur when making large payments to sitting politicians (Butler and Pereira 2018). ${ }^{17}$

After receiving the instructions, each participant then played four rounds as Player 1 . In each round, the participants were presented with a different profile for Player 2 (including their ethnicity, gender, age, and years served as councilor), given a reminder of how the game works, and then asked how many tokens they would like to send to Player 2 of that round. ${ }^{18}$ The ethnicity of Player 2 was randomized in each round, with each profile having an equal probability of being an ethnic Bosniak, Croat, or Serb. This means that officials played with a coethnic about one-third of the time. This randomization allows us to estimate whether respondents shared more tokens with coethnics than with others (i.e., the size of the coethnic bias). We can then test whether thinking about a shared pan-ethnic goal reduces this bias.

We test the hypothesis about the effect of shared interests by estimating whether those who were primed to think about EU benefits (i.e., the treatment group) show higher levels of trust toward non-coethnics than those in the control group. We do so by running a random effects regression model, which uses the respondent-round as observations and includes random effects for the respondents. ${ }^{19}$ The dependent variable is the number of tokens that the respondent shared with Player 2 that round. The model includes a dummy variable for whether Player 2 was a noncoethnic (Non-coethnic partner), a dummy variable for whether the respondent received the EU Benefits treatment, and an interaction term between the non-coethnic dummy and a treatment group dummy (Non-coethnic partner $\times E U$ benefits). The coefficient on the non-coethnic dummy quantifies how much less trust the respondents exhibited toward non-coethnics relative to coethnics, in the control condition. The interaction term then provides estimate of how much the coethnic bias is reduced when the respondent is primed to think about EU benefits.

\footnotetext{
${ }^{16}$ This was for logistical reasons dictated by the capabilities of the survey firm. A similar strategy is used in other studies, see Johnson and Mislin (2011) for a review.

${ }^{17}$ After the study was completed, we randomly chose one participant and one round of play, and paid those earnings $(\$ 1000)$ as a donation to the local school in the participant's municipality.

${ }^{18}$ Our instructions were ambiguous in two ways. First, we did not tell respondents what instructions player 2 received, although we set up the instructions such that they likely assumed their partner got the same instructions. Second, we did not tell respondents the city of player 2. Therefore, it is possible that officials may have assumed that coethnics were more likely than non-coethnics to be from their own city, which could increase the observed ethnic differences for reasons of city location and not ethnic bias. We think that the results are still informative for two reasons: (a) this experiment came after Experiment 1 where respondents were explicitly asked about officials from other cities, making it likely that they assumed that they would be playing against officials from other cities here too; (b) we don't have reasons to suspect that the EU treatment would change someone's preference for working with a local colleague, but for the reasons we lay out, it could affect their level of ethnic bias. In the end, we do not think that these omissions are driving the results.

${ }^{19}$ We present the random effects model because it allows us to estimate the direct effect of the treatment. Table OA6 presents models using fixed effects; those results are qualitatively the same.
} 
Table 2. The effect of shared pan-ethnic goals on interethnic trust

\begin{tabular}{|c|c|c|c|c|}
\hline $\begin{array}{l}\text { DV = Number of tokens to Player } 2 \\
\text { Sample: }\end{array}$ & $\begin{array}{l}(1) \\
\text { All }\end{array}$ & $\begin{array}{l}(2) \\
\text { Serbs }\end{array}$ & $\begin{array}{l}(3) \\
\text { Croats }\end{array}$ & $\begin{array}{c}\text { (4) } \\
\text { Bosniaks }\end{array}$ \\
\hline Non-coethnic partner & $\begin{array}{r}-0.86^{*} \\
(0.09)\end{array}$ & $\begin{array}{r}-1.11^{*} \\
(0.14)\end{array}$ & $\begin{array}{r}-1.01^{*} \\
(0.18)\end{array}$ & $\begin{array}{r}-0.60^{*} \\
(0.13)\end{array}$ \\
\hline EU Benefits treatment & $\begin{array}{c}-0.21 \\
(0.15)\end{array}$ & $\begin{array}{c}-0.24 \\
(0.24)\end{array}$ & $\begin{array}{c}-0.06 \\
(0.34)\end{array}$ & $\begin{array}{c}-0.20 \\
(0.22)\end{array}$ \\
\hline Non-coethnic partner $\times$ EU benefits & $\begin{array}{c}0.16 \\
(0.12)\end{array}$ & $\begin{array}{c}0.37^{\star} \\
(0.19)\end{array}$ & $\begin{array}{c}-0.08 \\
(0.25)\end{array}$ & $\begin{array}{c}0.09 \\
(0.18)\end{array}$ \\
\hline Constant & $\begin{array}{c}4.99^{\star} \\
(0.11)\end{array}$ & $\begin{array}{c}4.82^{*} \\
(0.18)\end{array}$ & $\begin{array}{c}5.00^{\star} \\
(0.25)\end{array}$ & $\begin{array}{c}5.10^{\star} \\
(0.16)\end{array}$ \\
\hline Observations & 5368 & 1960 & 928 & 2480 \\
\hline Individuals (\# Random effects) & 1342 & 490 & 232 & 620 \\
\hline
\end{tabular}

Notes: ${ }^{*} \mathrm{p} \leq 0.05$ (two-sided). Standard errors in parentheses.

\subsection{Experiment 2: results}

Table 2 provides the regression results, with column 1 representing the full sample, while columns 2-4 show the results for the various ethnic groups. ${ }^{20}$ All officials in the control condition exhibited lower levels of trust toward non-coethnic players: the coefficient on the Non-coethnic partner variable is negative and statistically significant in all models. The size of the bias is largest for the Serb respondents (with the bias among Croats being relatively similar) and lowest for Bosniaks. The difference in bias between Serbs and Bosniaks is statistically significant at the 0.05 level. In substantive terms, the coefficient of -1.1 indicates that Serbs send one less token (out of a possible 10 tokens) to non-coethnics than they send to coethnics, while Bosniaks send 0.6 fewer tokens to non-coethnics than they send to coethnics. As was the case in Experiment 1, with no other information available, respondents default to ethnicity in deciding who is trustworthy.

Can a reminder of shared pan-ethnic goals (in the form of potential EU membership) help overcome this bias in favor of coethnics? In column 1, which combines data for all ethnic groups, the coefficient for the interaction term does not come close to being statistically significant $(\mathrm{p}=$ 0.170). The results in columns 2-4 explore the effect among the three ethnic groups. These subgroup analyses are exploratory, i.e., they go beyond what we had planned for the experiment and they should be interpreted as such. These preliminary results show that the shared goals prime had its largest effect on the level of interethnic trust for the Serb respondents. ${ }^{21}$ Those Serb respondents who were primed to think about the benefits of EU membership gave their noncoethnic partners only 0.75 tokens less than they did to coethnic partners, compared to the 1.1 token difference in the control condition. Substantively, the 0.35 point reduction in ethnic bias is close to a third of the bias shown in the control condition. Further, the reduction is large enough to bring the level of bias close to the lower level exhibited by Bosniak officials.

It is notable that we observe a positive increase in the levels of trust among the Serbs, i.e., the group that initially exhibited the greatest preference for working with coethnics. It is also interesting that both studies uncovered the strongest effect among the same group: the Serbs. ${ }^{22}$ This

\footnotetext{
${ }^{20} \mathrm{OA} 4$ presents means and standard deviations of the dependent variable (i.e., number of tokens to player 2) for each of the three ethnic groups.

${ }^{21}$ We designed this prime to get officials to think about common interests and benefits that come with EU ascension. Another possibility is that the Serb officials were competitively oriented in both the treatment and control groups and that the treatment just caused them to reorient themselves toward competition between different countries instead of competition within their own country. Distinguishing between these two possibilities is another way in which this finding is exploratory.

${ }^{22} \mathrm{We}$ also looked at the treatment effects broken down by whether the respondent was an elected official (see Enemark et al. 2016) or someone who had run for office and lost (see Table OA5). The results showed that the effect of the EU prime is driven primarily by elected officials. The results also showed that elected officials were less likely to exhibit a coethnic favoritism in Experiment 1, but that with information about potential collaborators' preferences, the elected and non-elected
} 
consistency is encouraging and suggests that similar processes of reducing ethnic bias might be at play across the two studies. ${ }^{23}$

That said, the effects of Experiment 2 are weaker than those of Experiment 1 . The EU treatment had a noticeable change in the behavior of Serbs but not the behavior of the Croats and Bosniaks in the sample. Experiment 2 differs from Experiment 1 in several important ways, all of which could be responsible for the weaker results: (a) information about shared goals is subtler, (b) we consider a more diffuse form of out-group acceptance, one that does not imply an immediate tit-for-tat the way cooperation often does, and (c) the observed behavior is costly. While we cannot pinpoint the exact reason for the weaker results, it is clear that there are limits to what the priming about shared goals alone could do. Simply being reminded of abstract pan-ethnic goals (instead of concrete information on shared interests) may not be enough to generate generalized trust toward out-group members.

\section{Discussion and conclusion}

Our experiments revealed that, in Bosnia, ethnic divisions affect whether politicians want to cooperate with non-coethnics in governance. In both experiments, the individuals assigned to the control group exhibited a bias in favor of politicians from their own group. Our results show that shared interest can, at least in some cases, increase interethnic cooperation. In our first experiment, we found that politicians were more willing to work with a non-coethnic if they shared the same policy priority. This effect held across all three ethnic groups; the likelihood of interethnic cooperation increased by a third on average, and by a half for the Serbs. Our second experiment defined shared interests as more abstract, pan-ethnic goals and also looked at a more diffuse form of ethnic acceptance as revealed in a trust game. In this more demanding set-up, the priming treatment was less effective at changing politicians' bias for coethnics. Priming officials to think about the benefits of EU membership decreased coethnic favoritism only among Serb respondents.

Taken together, our results suggest that concrete information about shared policy priorities is effective at inducing expressed willingness of local politicians to cooperate with out-group members. National and international policy-makers can design funding schemes and other programs that provide incentives for finding common policy priorities across groups.

It is important, however, to keep in mind that our first experiment focuses on a situation where the bargaining is not zero-sum. The officials were asked about working with others in different cities. As a result, the politicians did not have to worry about fighting over the distribution of benefits within their city and both sides would benefit from cooperation. In zero-sum negotiations, the effects might be weaker. Our results cannot speak to that.

Similarly, our study focuses on municipal politicians. As described above, the real-world context of $\mathrm{BiH}$, particularly its consociational structure, the territorial separation of groups, and hierarchical, mono-ethnic parties, strongly discourages actual cross-ethnic cooperation among political elites. In this context, the local level provides the most incentives for cross-ethnic cooperation among elites. The extent to which our results generalize to elites in higher levels of government, where constraints on cooperation are stronger, is a question for future research.

Supplementary material. The supplementary material for this article can be found at https://doi.org/10.1017/psrm.2019.60

Acknowledgment. Funding for this research was provided by the Weidenbaum Center on the Economy, Government, and Public Policy.

\footnotetext{
elites in the sample showed comparable levels of preference for working with coethnics (i.e., the treatment effect was smaller for elected officials because they exhibited less favoritism to begin with in the first experiment).

${ }^{23}$ As noted in an earlier footnote, Serbs held preferences that were most different from the other two groups. They are also living in areas that are less ethnically diverse. For these reasons, the Croats and Bosniaks may already have been acquainted to the fact that the groups share interests and therefore be less affected by our treatment than Serbs.
} 


\section{References}

Abrajano MA and Alvarez RM (2005) A natural experiment of race-based and issue voting: the 2001 City of Los Angeles elections. Political Research Quarterly 58, 203-218.

Adida C (2015) Do African voters favor coethnics? A new identification strategy. Journal of Experimental Political Science 2, $1-11$.

Adida C, Gottlieb J, Kramon E and McClendon G (2017) Reducing or reinforcing in-group preferences? An experiment on information and ethnic voting. Quarterly Journal of Political Science 12, 437-477.

Avramovic I (2017) Reconciliation in Bosnia and Herzegovina. Beyond Intractability. Available at https://www.beyondintractability.org/casestudy/Avramovi\%C4\%87-Bosnia-Herzegovina.

Balliet D, Wu J and De Dreu CKW (2014) Ingroup favoritism in cooperation: a meta-analysis. Psychological Bulletin 140, 1556-1581.

Bates RH (1983) Modernization, ethnic competition and the rationality of politics in Contemporary Africa. In Rothchild D and Olorunsola VA (eds), State versus Ethnic Claims: African Policy Dilemmas. Boulder, CO: Westview, pp. 152-171.

Bouckaert J and Dhaene G (2004) Inter-Ethnic trust and reciprocity: results of an experiment with small businessmen. European Journal of Political Economy 20, 869-886.

Burgess R, Jedwab R, Miguel E, Morjaria A and Padro i Miguel G (2015) The value of democracy: evidence from road building in Kenya. American Economic Review 105, 1817-1851.

Busby M (2018) Frozen sectarian divisions hear up in Bosnia. New Internationalist, 21 February. https://newint.org/features/ web-exclusive/2018/02/21/bosnia-dayton-agreement-fragile-peace.

Butler DM and Kousser T (2015) How do public goods providers play public goods games? Legislative Studies Quarterly 40, 211-240.

Butler DM and Pereira MM (2018) Are donations to charity an effective incentive for public officials? Journal of Experimental Political Science 5, 68-70.

Carlson E (2015) Ethnic voting and accountability in Africa: a choice experiment in Uganda. World Politics 67, 353-385.

Chandra K (2004) Why Ethnic Parties Succeed: Patronage and Ethnic Head Counts in India. Cambridge: Cambridge University Press.

Chandra K (2005) Ethnic parties and democratic stability. Perspectives on Politics 3, 235-252.

Coser LA (1956) The Functions of Social Conflict. New York: Free Press.

De Figueiredo R and Weingast B (1999) The rationality of fear: political opportunism and ethnic conflict. In Walter BF and Snyder J (eds), Civil Wars, Insecurity, and Intervention. New York: Columbia University Press, pp. 261-302.

Dunning T and Harrison L (2010) Cross-cutting cleavages and ethnic voting: an experimental study of Cousinage in Mali. American Political Science Review 104, 21-39.

Enemark D, Gibson CC, McCubbins MD and Seim B (2016) Effect of holding office on the behavior of politicians. PNAS: Proceedings of the National Academy of Sciences 113, 13690-13695.

Ferree K (2006) Explaining South Africa's racial census. Journal of Politics 68, 803-815.

Franck R and Rainer I (2012) Does the leader's ethnicity matter? Ethnic favoritism, education, and health in Sub-Saharan Africa. American Political Science Review 106, 294-325.

Gaertner SL, Dovidio JF, Banker BS, Houlette M, Johnson KM and McGlynn EA (2000) Reducing intergroup conflict: from superordinate goals to decategorization, recategorization, and mutual differentiation. Group Dynamics: Theory, Research, and Practice 4, 98-114.

Gibson J (2004) Overcoming Apartheid: Can Truth Reconcile a Divided Nation? New York: Russell Sage Foundation.

Gubler JA and Selway JS (2012) Horizontal inequality, crosscutting cleavages, and civil war. Journal of Conflict Resolution 56, 206-232.

Gurr TR (2000) Peoples versus States: Minorities at Risk in the New Century. Washington, DC: U.S. Institute of Peace.

Habyarimana J, Humphreys M, Posner DN and Weinstein JM (2007) Why does ethnic diversity undermine public goods provision? American Political Science Review 101, 709-725.

Hale HE (2004) Explaining ethnicity. Comparative Political Studies 37, 458-485.

Hewstone M, Rubin M and Willis H (2002) Intergroup bias. Annual Review of Psychology 53, 575-604.

Horowitz D (1985) Ethnic Groups in Conflict. Berkeley and Los Angeles: University of California Press.

Huber JD (2012) Measuring ethnic voting: do proportional electoral laws politicize ethnicity? American Journal of Political Science 56, 986-1001.

Ichino N and Nathan NL (2013) Local ethnic geography and instrumental ethnic voting: voter behavior across rural Ghana. American Political Science Review 107, 344-361.

Iyengar S and Westwood SJ (2015) Fear and loathing across party lines: new evidence on group polarization. American Journal of Political Science 59, 690-707.

Johnson ND and Mislin AA (2011) Trust games: a meta-analysis. Journal of Economic Psychology 32, 865-889.

Jokay C (2001) Local government in Bosnia and Herzegovina. In Kandeva E (ed.), Stabilization of Local Governments. Budapest, Hungary: Open Society Institute, pp. 89-140.

Kapidzic D (2016) Local elections in Bosnia and Herzegovina. Contemporary Southeastern Europe 3, 127-134. 
Keil S and Kudlenko A (2015) Bosnia and Herzegovina 20 years after Dayton: complexity born of paradoxes. International Peacekeeping 22, 471-489.

Keil S and Perry V (2015) Back to square one? An analysis of the 2014 general elections in Bosnia and Herzegovina. Electoral Studies 38, 82-87.

Kramon E and Posner DN (2016) Ethnic favoritism in education in Kenya. Quarterly Journal of Political Science 11, 1-58.

Laitin D (1986) Hegemony and Culture: Politics and Religious Change Among the Yoruba. Chicago: The University of Chicago Press.

LeVeck BL, Hughes DA, Hafner-Burton E, Fowler JH and Victor DG (2014) The role of self-interest in elite bargaining. Proceedings of the National Academy of Sciences 111, 18536-18541.

Lieberman ES and McClendon GH (2013) The ethnicity-policy preference link in Sub-Saharan Africa. Comparative Political Studies 46, 574-602.

Lijphart A (2012) Patterns of Democracy. New Haven: Yale University Press.

Lipset SM (1960) Political Man. Garden City: Doubleday.

McClendon GH (2016) Race and responsiveness: an experiment with South African politicians. Journal of Experimental Political Science 3, 60-74.

Michelitch K (2015) Does electoral competition exacerbate interethnic or interpartisan economic discrimination? Evidence from a field experiment in market price bargaining. American Political Science Review 109, 43-61.

Mummolo J and Peterson E (2019) Demand effects in survey experiments: an empirical assessment. American Political Science Review 113, 517-529.

Posner D (2005) Institutions and Ethnic Politics in Africa. Cambridge: Cambridge University Press.

Rabbie JM, Schot JC and Visser L (1989) Social identity theory: a conceptual and empirical critique from the perspective of a behavioural interaction model. European Journal of Social Psychology 19, 171-202.

Robinson AL (2016a) Internal borders: ethnic-based market segmentation in Malawi. World Development 87, $371-384$.

Robinson AL (2016b) Nationalism and ethnic-based trust: evidence from an African Border Region. Comparative Political Studies 49, 1819-1854.

Rothchild DS (1997) Managing Ethnic Conflict in Africa: Pressures and Incentives for Cooperation. Washington, DC: Brookings Institution Press.

Šedo J (2010) The party systems of Bosnia and Herzegovina. In Stojarová V and Emerson P (eds), Party Politics in the Western Balkans. New York, NY: Routledge, pp. 85-98.

Sherif M (1966) In Common Predicament: Social Psychology of Intergroup Conflict and Cooperation. Boston: Houghton Mifflin Company.

Stojarová V (2010) Nationalist parties and the party systems of the Western Balkans. In Stojarová V and Emerson P (eds), Party Politics in the Western Balkans. Routledge: New York, NY, pp. 42-58.

Tavits M and Potter JD (2015) The effect of inequality and identity on party strategies. American Journal of Political Science 59, 744-758.

White A, Strezhnev A, Lucas C and Kruszewska D (2018) Investigator characteristics and respondent behavior in online surveys. Journal of Experimental Political Science 5, 56-67.

Whitt S (2010) Institutions and ethnic trust: evidence from Bosnia. Europe-Asia Studies 62, 271-292.

Whitt S and Wilson RK (2007) The dictator game, fairness and ethnicity in Postwar Bosnia. American Journal of Political Science 51, 655-668.

World Bank (2009) From Stability to Performance: Local Governance and Service Delivery in Bosnia and Herzegovina. Washington, DC: World Bank.

Yamagishi T, Jin N and Kiyonari T (1999) Bounded generalized reciprocity: ingroup boasting and ingroup favoritism. In Lawler EJ (Series ed.) and Thye SR, Lawler EJ, Macy MW and Walker HA (Vol. eds.), Advances in Group Processes. Bingley, England: Emerald, pp. 161-197.

Cite this article: Butler D, Tavits M (2021). Shared interests foster interethnic cooperation among politicians. Political Science Research and Methods 9, 627-640. https://doi.org/10.1017/psrm.2019.60 